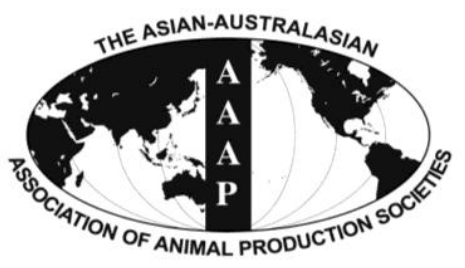

Asian-Aust. J. Anim. Sci.

Vol. 25, No. $10: 1419$ - 1429

October 2012

www.ajas.info

http://dx.doi.org/10.5713/ajas.2012.12184

\title{
Effects of Dietary Garlic Extracts on Whole Body Amino Acid and Fatty Acid Composition, Muscle Free Amino Acid Profiles and Blood Plasma Changes in Juvenile Sterlet Sturgeon, Acipenser ruthenus
}

\author{
Dong-Hoon Lee, Seong-Ryul Lim, Chang-Six Ra ${ }^{1}$ and Jeong-Dae Kim ${ }^{1}{ }^{\text {* }}$ \\ Gyenoggi Province Freshwater Fisheries Research Institute, \\ 235-1 Kwangtan-Ri, Yangpyeong-Gun, Gyeonggi-Do, 476-841, Korea
}

\begin{abstract}
A series of studies were carried out to investigate the supplemental effects of dietary garlic extracts (GE) on whole body amino acids, whole body and muscle free amino acids, fatty acid composition and blood plasma changes in 6 month old juvenile sterlet sturgeon (Acipenser ruthenus). In the first experiment, fish with an average body weight of $59.6 \mathrm{~g}$ were randomly allotted to each of 10 tanks (two groups of five replicates, 20 fish/tank) and fed diets with (0.5\%) or without (control) GE respectively, at the level of $2 \%$ of fish body weight per day for 5 wks. Whole body amino acid composition between the GE and control groups were not different ( $>>0.05$ ). Among free amino acids in muscle, L-glutamic acid, L-alanine, L-valine, L-leucine and L-phenylalanine were significantly $(\mathrm{p}<0.05)$ higher in GE than in control. However, total whole body free amino acids were significantly lower in GE than in control $(\mathrm{p}<0.05)$. GE group showed higher EPA $(\mathrm{C} 22: 6 \mathrm{n} 3)$ and DHA $(\mathrm{C} 22: 5 \mathrm{n} 3)$ in their whole body than the other group (p<0.05). In the second experiment, the effects of dietary garlic extracts on blood plasma changes were investigated using 6 month old juvenile sterlet sturgeon averaging $56.5 \mathrm{~g}$. Fish were randomly allotted to each of 2 tanks (300 fish/tank) and fed diets with $(0.5 \%)$ or without (control) GE respectively, at the rate of $2 \%$ of body weight per day for $23 \mathrm{~d}$. At the end of the feeding trial, blood was taken from the tail vein $(\mathrm{n}=5$, per group) at 1, 12, and $24 \mathrm{~h}$ after feeding, respectively. Blood plasma glucose, insulin and the other serological characteristics were also measured to assess postprandial status of the fish. Plasma glucose concentrations (mg/dl) between two groups (GE vs control) were significantly ( $\mathrm{p}<0.05)$ different at $1(50.8$ vs 62.4$)$ and 24 h (57.6 vs 73.6) after feeding, respectively, while no significant difference ( $>0.05$ ) were noticed at $12 \mathrm{~h}$ (74.6 vs 73.0). Plasma insulin concentrations ( $\mu \mathrm{IU} / \mathrm{ml}$ ) between the two groups were significantly ( $\mathrm{p}<0.05)$ different at 1 (10.56 vs 5.06) and $24 \mathrm{~h}$ (32.56 vs 2.96) after feeding. The present results suggested that dietary garlic extracts could increase dietary glucose utilization through the insulin secretion, which result in improved fish body quality and feed utilization by juvenile sterlet sturgeon. (Key Words: Garlic Extracts, Sterlet Sturgeon, Fatty Acids, Amino Acids, Free Amino Acids, Insulin, Glucose)
\end{abstract}

\section{INTRODUCTION}

Sturgeon is one of the oldest species of living vertebrates and often described as "living fossils", with records dating back more than 150 million years. Today, the sturgeon is recognized as one of the world's most precious commercial fish, mainly prized for its caviar, but increasingly also for its meat and as an ornamental fish (Mims et al., 2000). Most sturgeon species are bottom

\footnotetext{
* Corresponding Author: Jeong-Dae Kim. Tel: +82-33-2508633, Fax: +82-33-2555482, E-mail: menzang@gmail.com

${ }^{1}$ Department of Animal Life System, College of Animal Life Sciences, Kangwon National University, Chuncheon 200-701, Korea.

Submitted Apr. 9, 2012; Accepted Jun. 11, 2012; Revised Jun. 13, 2012
}

dwellers and feed benthically on insect larvae and small fish (Hochleithner and Gessner, 1999). In Korea, sturgeon aquaculture has begun in 1996 with the main species for sterlet sturgeon (Acipenser ruthenus), Siberian (A. baeri), Russian (A. gueldenstaedti), stellate (A. stellatus) and hybrid called bester (beluga femalexsterlet male).

One of the commonest interests in fish farming worldwide is how to diminish production cost and extend outputs in the shortest time. One method is to include new substances into fish diets to improve feed conversion efficiency or elevate general conditions for fish growth and maintenance (Fernández-Navarro et al., 2006). Plant products have been reported to promote various activities like antistress, growth promotion, appetite stimulation and immunostimulation in aquaculture practices (Citarasu et al., 2001, 2002; Sivaram et al., 2004). Garlic (Allium sativum) 
is a perennial bulb-forming plant that belongs to the genus Allium in the family Liliaceae. Garlic has been used for centuries as a flavouring agent, traditional medicine, and a functional food to enhance physical and mental health. Dietary garlic decreases blood glucose by increasing the level of serum insulin (Ahmed and Sharma, 1997) and the $\mathrm{S}$-allylcysteine sulfoxide present in garlic is responsible for its hypoglycaemic activity (Sheela and Augusti, 1992). Dietary garlic as a growth promoter in Nile tilapia (Oreochromis niloticus) improved body weight gain, feed intake and feed efficiency (Diab et al., 2002; Shalaby et al., 2006). Our previous research suggested dietary garlic for juvenile sterlet sturgeon (60 to $100 \mathrm{~g}$ ) could positively affect growth performance (Lee et al., 2008, Lee et al., 2012). But, no trial was conducted to study the effect of dietary garlic extracts on meat quality and metabolic effects of blood plasma for sterlet sturgeon till date. Therefore, this study was designed to investigate the effects of garlic extracts on whole body amino acids and fatty acids composition, as well as blood plasma changes of the fish.

\section{MATERIALS AND METHODS}

\section{Preparation of garlic extract}

Two kg of garlic (Allium satium) powders obtained from the local market in Gyeonggi Province, Korea were left during $48 \mathrm{~h}$ in $99 \%$ ethanol $20 \mathrm{~L}(10 \% \mathrm{w} / \mathrm{v})$ at room temperature $\left(20 \pm 2^{\circ} \mathrm{C}\right)$, and the resulting extract was concentrated to $300 \mathrm{ml}$ using rotary evaporator (DPE 1210 NE Series, EYELA. Japan), giving the extract of $6.7 \mathrm{~g}$ of garlic powder/ml. This extract was sprayed on the diet after dilution in $300 \mathrm{ml}$ of distilled water.

\section{Experimental design and diets}

Juvenile sterlet sturgeons (Acipenser ruthenus) were obtained from Gyeonggi Province Freshwater Fisheries Research Institute, Gyeonggido, Korea. The first experiment was carried out to investigate the supplemental effect of dietary GE on whole body amino acid and fatty acid composition of juvenile sterlet sturgeon with average body weight $59.6 \mathrm{~g}$. For which, two hundred fish selected from 2,000 fish were randomly allotted to each of 10 tanks (two groups of five replicates, 20 fish/tank). Fish were cultured in semi-recirculation freshwater system. Water temperature and dissolved oxygen levels were kept at $22 \pm 1^{\circ} \mathrm{C}$ and over $6 \mathrm{mg} \mathrm{O} \mathrm{O}^{-1}$, respectively. Flow rate was adjusted at a minimum of $3 \mathrm{~L} \mathrm{~min}^{-1}$. A commercial extruded pellet of $1.7 \mathrm{~mm}$ size (Cargil Agri Purina Inc., Korea) was used as the experimental diet. The diets were prepared to contain $0 \% \mathrm{GE}$ (Control) and $0.5 \% \mathrm{GE}$ (diet $20 \mathrm{~kg}+100 \mathrm{ml}$ garlic extract $+300 \mathrm{ml}$ distilled water) garlic extract. The mixture of garlic extract and distilled water was sprayed on the experimental diets, which were then dried in a dryer
(GCT-104OR-4G, Fresh and Cool Technology Ltd., Korea) at $30^{\circ} \mathrm{C}$ for $48 \mathrm{~h}$ in order to volatilize remaining ethanol. The commercial diet was chemically analyzed to contain moisture $9.2 \%$, crude protein $47.8 \%$, crude fat $8.9 \%$ and crude ash $8.8 \%$. Chemical composition of GE diet was analyzed to be same (moisture $9.6 \%$, crude protein $47.6 \%$, crude fat $8.7 \%$ and crude ash $8.8 \%$ ). Five replicate groups of fish were fed the experimental diets by hand at the rate of $2 \%$ of fish body weight per day at 08:00 h, 13:00 h and 18:00 h, for $5 \mathrm{wks}$.

The second trial was carried out to investigate the supplemental effect of dietary GE on blood plasma changes of 6 month old juvenile sterlet sturgeon averaging $56.5 \mathrm{~g}$. Fish were cultured in running freshwater system in which water temperature and dissolved oxygen were maintained at $21 \pm 1^{\circ} \mathrm{C}$ and over $7 \mathrm{mg} \mathrm{O}_{2} \mathrm{~L}^{-1}$, respectively. Flow rate was adjusted at a minimum of $100 \mathrm{~L} \mathrm{~min}^{-1}$. Fish were randomly allotted to each of 2 tanks (300 fish/tank, tank size, $\oint 4 \times 0.6$ $\mathrm{m})$. Same diets used in the first experiment were employed. Diets were fed by hand at the rate of $2 \%$ of body weight per day at 08:00 h, 13:00 $\mathrm{h}$ and 18:00 h, respectively for 23 days.

\section{Sample collection and analysis}

At the end of the first trial, fish were anesthetized with AQUI-S (New Zealand Ltd., NZ) and then all fish in each tank were individually weighed and each five fish from each replication of two groups were selected at equivalent weight to analyze whole body amino acid and fatty acid composition, respectively. Each five fish from each replication of two groups were selected at equivalent weight to analyze free amino acid profiles of dorsal muscle. Blood samples were obtained from the caudal vessels with a heparinized syringe from each five fish of two groups after fish were starved for $24 \mathrm{~h}$ and anesthetized with AQUI-S. Hematocrit (PCV) and hemoglobin ( $\mathrm{Hb})$ were measured with the same fish by the microhematocrit method (Brown, 1980) and the cyan-methemoglobin procedure using Drabkins solution, respectively. Hb standard prepared from human blood (Sigma Chemical, St. Louis, Missoruri) was used. The amino acids and free amino acids were quantified by the amino acid analyzer S433 (Syknm, Germany) using ninhydrin method. Analysis conditions were as follows: column size, $4 \mathrm{~mm} \times 150 \mathrm{~mm}$; absorbance, $570 \mathrm{~nm}$ and 440 $\mathrm{nm}$; reagent flow rate, $0.25 \mathrm{ml} / \mathrm{min}$; buffer flow rate, 0.45 $\mathrm{ml} / \mathrm{min}$; reactor temperature, $120^{\circ} \mathrm{C}$ and reactor size, $15 \mathrm{~m}$. Fish were stored at $-20^{\circ} \mathrm{C}$ until analysis. Fatty acid methyl esters were obtained by direct transesterification (Metclfe et al., 1996) and analyzed by gas chromatography using a Trace GC gas chromatograph (Thermo Finigan, USA) equipped with a silica capillary column (Quadrex, $30 \mathrm{M}$, bonded carbowax $0.25 \mathrm{~mm}$ I.D $\times 0.25 \mu \mathrm{m}$ film, No 007-CW$30-0.25 \mathrm{~F}$, USA) and flame ionization detector (FID). 
Helium was used as carrier gas. The column temperature was programmed at $100^{\circ} \mathrm{C}$ from $200^{\circ} \mathrm{C}\left(5^{\circ} \mathrm{C} / \mathrm{min}\right)$ and at $220^{\circ} \mathrm{C}$ from $240^{\circ} \mathrm{C}\left(3^{\circ} \mathrm{C} / \mathrm{min}\right)$, and injector and detector were maintained at $200^{\circ} \mathrm{C}$ and $250^{\circ} \mathrm{C}$, respectively.

At the end of the second feeding trial, chemical analyses of fish liver were performed by the standard procedure of AOAC (1995) for moisture, crude protein and crude ash. Crude lipid was determined using the Soxtec system 1046 (Tecator AB, Sweden) after freeze-drying the samples for $12 \mathrm{~h}$. Blood samples were taken from the caudal vessels of five fish from each group by using a heparinized syringe after fish were starved for 1,12 and $24 \mathrm{~h}$ and anesthetized with AQUI-S. Blood plasma were obtained after blood centrifugation $\left(3,500 \times \mathrm{g}, 5 \mathrm{~min}, 4^{\circ} \mathrm{C}\right)$ and stored at $-80^{\circ} \mathrm{C}$ until glucose, insulin, GOT (glutamic oxaloacetic transaminase), GPT (glutamic pyruvic transaminase), TP (total protein), ALB (albumin), TG (triglyceride) and TCHO (total cholesterol) were analyzed. Plasma insulin was measured by a solid phase ${ }^{125} \mathrm{I}$ radioimmunoassay (RIA) kit

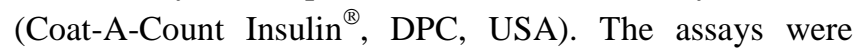
performed as described in the manufacture protocol. Standard solutions, samples and ${ }^{125} \mathrm{I}$ tracer were added to duplicate antibody-coated assay tubes. Tubes were incubated at 20 to $24^{\circ} \mathrm{C}$ (room temperature) for 18 to $24 \mathrm{~h}$. Tubes were decanted and radioactivity remaining bound to the tubes was quantified using a gamma counter (1470 Wizard, PerkinElmer Ltd, Finland). Concentrations of insulin in samples were calculated from logit-log representation of the standard curves (Stimmelmary et al., 2002). The plasma glucose, GOT, GPT, TP, TG and TCHO were measured using a blood chemical analyzer (DRICHEM 3500 I, Fujifilm Ltd. Japan) with commercial clinical investigation kit (Fuji DRI-CHEM slide, Fuji photo flim co. Ltd., Japan).

\section{Statistical analysis}

Data of Exp. 1 (amino acid and fatty acid compositions) and Exp. 2 (crude protein, crude lipid and crude ash) were analyzed using one-way analysis of variance (ANOVA) and significant differences among treatment means were compared using Duncan's multiple range test (Duncan, 1955). Significance was tested at 5\% level and all statistical analyses were carried out using the SPSS Version 10 (SPSS, Michigan Avenue, Chicago, IL, USA). Statistical analysis among individuals having single value without replicate within group, such as Exp. 1 (PCV and $\mathrm{Hb}$ ) and Exp. 2 (Glucose, Insulin, GOT, GPT, ALB, TP, TCHO, TG and HSI) were evaluated by the Wilcoxon test and Friedman test (Zimmerman and Zumbo, 1993). Statistical significance of the differences was determined by a significant level of $5 \%$ $(\mathrm{p}<0.05)$.

\section{RESULTS}

\section{Whole body amino acid composition}

The amino acid composition of the whole body is shown in Table 1. Total amino acid content of the initial

Table 1. Amino acid composition (\%, as-is basis) in whole body of juvenile sterlet sturgeon fed diets for 5 wks ${ }^{1}$

\begin{tabular}{|c|c|c|c|c|}
\hline \multirow{2}{*}{ Free amino acid } & \multirow{2}{*}{ Diet } & \multirow{2}{*}{ Initial } & \multicolumn{2}{|c|}{ Experimental groups } \\
\hline & & & Control & GE \\
\hline Aspartic acid & $4.46 \pm 0.05$ & $1.73 \pm 0.04^{\mathrm{ns}}$ & $1.74 \pm 0.09$ & $1.67 \pm 0.17$ \\
\hline Threonine & $1.54 \pm 0.08$ & $0.46 \pm 0.02^{\mathrm{ns}}$ & $0.44 \pm 0.03$ & $0.45 \pm 0.02$ \\
\hline Serine & $2.04 \pm 0.06$ & $0.49 \pm 0.02^{\mathrm{ns}}$ & $0.50 \pm 0.03$ & $0.50 \pm 0.01$ \\
\hline Glutamic acid & $8.13 \pm 0.15$ & $2.11 \pm 0.30^{\mathrm{ns}}$ & $1.83 \pm 0.04$ & $1.94 \pm 0.08$ \\
\hline Proline & $2.46 \pm 0.01$ & $0.65 \pm 0.03^{\mathrm{ns}}$ & $0.65 \pm 0.03$ & $0.65 \pm 0.02$ \\
\hline Glycine & $2.52 \pm 0.08$ & $1.01 \pm 0.01^{\mathrm{a}}$ & $0.90 \pm 0.02^{\mathrm{b}}$ & $0.91 \pm 0.01^{\mathrm{b}}$ \\
\hline Alanine & $2.87 \pm 0.02$ & $0.76 \pm 0.03^{\mathrm{ns}}$ & $0.80 \pm 0.03$ & $0.78 \pm 0.01$ \\
\hline Valine & $2.41 \pm 0.02$ & $0.70 \pm 0.04^{\mathrm{ns}}$ & $0.69 \pm 0.04$ & $0.70 \pm 0.03$ \\
\hline Isoleucine & $1.94 \pm 0.02$ & $0.55 \pm 0.02^{\mathrm{ns}}$ & $0.57 \pm 0.06$ & $0.56 \pm 0.03$ \\
\hline Leucine & $3.96 \pm 0.05$ & $1.17 \pm 0.03^{\mathrm{ns}}$ & $1.19 \pm 0.08$ & $1.18 \pm 0.04$ \\
\hline Tyrosine & $1.82 \pm 0.04$ & $0.29 \pm 0.03^{\mathrm{ns}}$ & $0.29 \pm 0.03$ & $0.29 \pm 0.01$ \\
\hline Phenylalanine & $2.00 \pm 0.05$ & $0.51 \pm 0.03^{\mathrm{ns}}$ & $0.46 \pm 0.05$ & $0.46 \pm 0.03$ \\
\hline Histidine & $1.18 \pm 0.02$ & $0.33 \pm 0.07^{\mathrm{ns}}$ & $0.27 \pm 0.03$ & $0.30 \pm 0.04$ \\
\hline Lysine & $3.07 \pm 0.04$ & $1.56 \pm 0.09^{\mathrm{a}}$ & $1.25 \pm 0.10^{\mathrm{b}}$ & $1.26 \pm 0.07^{\mathrm{b}}$ \\
\hline Arginine & $2.92 \pm 0.00$ & $1.01 \pm 0.02^{\mathrm{a}}$ & $0.84 \pm 0.07^{b}$ & $0.88 \pm 0.03^{b}$ \\
\hline Cysteine & $0.58 \pm 0.04$ & $0.15 \pm 0.01^{\mathrm{ns}}$ & $0.15 \pm 0.01$ & $0.15 \pm 0.01$ \\
\hline Methionine & $1.10 \pm 0.07$ & $0.30 \pm 0.02^{\mathrm{ns}}$ & $0.27 \pm 0.02$ & $0.29 \pm 0.01$ \\
\hline Total & $44.83 \pm 0.18$ & $13.77 \pm 0.12^{\mathrm{a}}$ & $12.85 \pm 0.42^{b}$ & $12.94 \pm 0.21^{b}$ \\
\hline
\end{tabular}

${ }^{1}$ Values are means \pm SE of five replicates with 2 determinations per replicate for initial and each final group. Means with different superscripts in the same row are significantly different $(\mathrm{p}<0.05)$. $\mathrm{ns}=$ Nonsignificant $(\mathrm{p}>0.05)$. 
group was higher than that of the other final groups $(p<0.05)$. Difference in levels of total amino acid among initial and final groups was observed in three amino acids, glycine, lysine and arginine. Whole body amino acid composition between GE and control groups were not different $(\mathrm{p}>0.05)$.

\section{Whole body free amino acid composition}

Levels of free amino acid in whole body are shown in Table 2. GE group showed lower levels of free amino acids than control group $(\mathrm{p}<0.05)$. However, individual free amino acid levels among three groups are not different ( $>0.05$ ) except for six free amino acids, L-serine, L-glycine, L-alanine, $\beta$-alanine, L-lysine and L-histidine $(\mathrm{p}<0.05)$.

\section{Muscle free amino acid composition}

The free amino acid composition in muscle of juvenile sterlet sturgeon fed diets with or without GE is shown in Table 3. Major free amino acids in muscle of two fish groups were ornithine, histidine, alanine and taurine. Muscle contained significantly higher $(p<0.05)$ glutamic acid, alanine, valine, leucine and phenylalanine for fish fed GE than for those fed control. Total free amino acid level in muscle was 0.267 to $0.337 \mathrm{mg} / 100 \mathrm{mg}$ for control and GE

Table 2. Free amino acid composition ( $\mathrm{mg} / 100 \mathrm{mg}$, as-is basis) in whole body of juvenile sterlet sturgeon fed diets for $5 \mathrm{wks}^{1}$

\begin{tabular}{|c|c|c|c|}
\hline \multirow{2}{*}{ Free amino acid } & \multirow{2}{*}{ Initial } & \multicolumn{2}{|c|}{ Experimental groups } \\
\hline & & Control & $\mathrm{GE}$ \\
\hline Phosphoserine & $0.001 \pm 0.006^{\mathrm{ns}}$ & $0.002 \pm 0.001$ & $0.001 \pm 0.000$ \\
\hline Taurine & $0.046 \pm 0.008^{\mathrm{ns}}$ & $0.038 \pm 0.002$ & $0.026 \pm 0.011$ \\
\hline L-aspartic acid & $0.001 \pm 0.006^{\mathrm{ns}}$ & $0.001 \pm 0.008$ & $\mathrm{ND}^{2}$ \\
\hline L-threonine & $0.007 \pm 0.003^{\mathrm{ns}}$ & $0.010 \pm 0.004$ & $0.005 \pm 0.000$ \\
\hline L-serine & $0.007 \pm 0.002^{\mathrm{a}}$ & $0.003 \pm 0.001^{\mathrm{b}}$ & $0.006 \pm 0.001^{\mathrm{a}}$ \\
\hline L-glutamic acid & $0.013 \pm 0.001^{\mathrm{ns}}$ & $0.013 \pm 0.004$ & $0.008 \pm 0.000$ \\
\hline L-glycine & $0.010 \pm 0.002^{\mathrm{b}}$ & $0.016 \pm 0.002^{\mathrm{a}}$ & $0.009 \pm 0.001^{\mathrm{b}}$ \\
\hline L-alanine & $0.017 \pm 0.003^{b}$ & $0.023 \pm 0.003^{\mathrm{a}}$ & $0.014 \pm 0.001^{\mathrm{b}}$ \\
\hline L-valine & $0.005 \pm 0.002^{\mathrm{ns}}$ & $0.007 \pm 0.002$ & $0.004 \pm 0.001$ \\
\hline L-isoleucine & $0.005 \pm 0.001^{\mathrm{ns}}$ & $0.005 \pm 0.001$ & $0.003 \pm 0.001$ \\
\hline L-leucine & $0.008 \pm 0.002^{\mathrm{ns}}$ & $0.011 \pm 0.003$ & $0.006 \pm 0.001$ \\
\hline L-tyrosine & $0.005 \pm 0.002^{\mathrm{ns}}$ & $0.007 \pm 0.002$ & $0.005 \pm 0.001$ \\
\hline L-phenylalanine & $0.006 \pm 0.002^{\mathrm{ns}}$ & $0.007 \pm 0.002$ & $0.005 \pm 0.001$ \\
\hline$\beta$-Alanine & $0.008 \pm 0.001^{\mathrm{b}}$ & $0.016 \pm 0.002^{\mathrm{a}}$ & $0.011 \pm 0.005^{\mathrm{ab}}$ \\
\hline L-lysine & $0.005 \pm 0.001^{\mathrm{b}}$ & $0.010 \pm 0.004^{\mathrm{a}}$ & $0.005 \pm 0.001^{\mathrm{b}}$ \\
\hline L-histidine & $0.004 \pm 0.000^{\mathrm{b}}$ & $0.009 \pm 0.002^{\mathrm{a}}$ & $0.006 \pm 0.001^{\mathrm{b}}$ \\
\hline L-arginine & $0.045 \pm 0.018^{\mathrm{ns}}$ & $0.065 \pm 0.002$ & $0.042 \pm 0.017$ \\
\hline Total & $0.195 \pm 0.009^{\mathrm{b}}$ & $0.243 \pm 0.027^{\mathrm{a}}$ & $0.157 \pm 0.034^{\mathrm{b}}$ \\
\hline
\end{tabular}

Table 3. Free amino acid composition ( $\mathrm{mg} / 100 \mathrm{mg}$, as-is basis) in muscle of juvenile sterlet sturgeon fed diets for $5 \mathrm{wks}^{1}$

\begin{tabular}{lcc}
\hline \multirow{2}{*}{ Free amino acid } & \multicolumn{2}{c}{ Experimental groups } \\
\cline { 2 - 3 } & $0.001 \pm 0.000$ & $0.003 \pm 0.002$ \\
\hline Phosphoserine & $0.039 \pm 0.009$ & $0.031 \pm 0.008$ \\
Taurine & $0.022 \pm 0.008$ & $0.034 \pm 0.003^{*}$ \\
L-glutamic acid & $0.006 \pm 0.003$ & $0.012 \pm 0.005$ \\
L-proline & $0.007 \pm 0.002$ & $0.011 \pm 0.003$ \\
L-glycine & $0.022 \pm 0.005$ & $0.054 \pm 0.005^{*}$ \\
L-alanine & $0.006 \pm 0.003$ & $0.016 \pm 0.002^{*}$ \\
L-valine & $0.004 \pm 0.003$ & $0.009 \pm 0.002$ \\
L-isoleucine & $0.007 \pm 0.004$ & $0.017 \pm 0.004^{*}$ \\
L-leucine & $0.005 \pm 0.001$ & $\mathrm{ND}$ \\
L-tyrosine & $0.003 \pm 0.002$ & $0.008 \pm 0.001^{*}$ \\
L-phenylalanine & $0.035 \pm 0.011$ & $0.039 \pm 0.011$ \\
$\beta$-Alanine & $0.007 \pm 0.001$ & $0.005 \pm 0.002$ \\
$\gamma$-Aminobutyric acid & $0.048 \pm 0.006$ & $0.040 \pm 0.005$ \\
L-ornithine & $0.005 \pm 0.004$ & $0.005 \pm 0.001$ \\
1-methyl-L-histidine & $0.046 \pm 0.006$ & $0.051 \pm 0.011$ \\
3-methyl-L-histidine & $0.267 \pm 0.041$ & $0.337 \pm 0.012^{*}$ \\
Total &
\end{tabular}

Values are means \pm SE of five replicates with 2 determinations per replicate for control and GE group. Mean with the asterisk* in the same row indicates significant difference $(\mathrm{p}<0.05)$ between two experimental groups.

${ }^{2}$ Not detected.

groups, respectively, which was found to be significantly different $(\mathrm{p}<0.05)$.

\section{Whole body fatty acid composition}

The fatty acid profile of the experimental diet and whole body of initial and final sturgeon fed the experimental diets for 5 wks is shown in Table 4. In both initial and final fish, $18: 1 \mathrm{n} 9,16: 0$ and 18:2n6 were observed to be dominant fatty acids, of which 18:1n9 and 16:0 showed a significant decrease $(p<0.05)$ from $30.1 \%$ for initial to $29.3 \%$ and $26.8 \%$ and from $24.9 \%$ for initial to $22.5 \%$ and $21.3 \%$ for control and GE, respectively. However, a slight increase in $18: 2 \mathrm{n} 6$ from $12.4 \%$ for initial to $13.4 \%$ and $14.0 \%$ was found for control and GE, respectively. Final fish showed more prominent increase $(p<0.05)$ in $20: 5 n 3$ and $22: 6 n 3$ compared to initial. The former was increased from $2.1 \%$ for initial to $3.3 \%$ and $4.2 \%$ and the latter from $5.2 \%$ for initial to $7.3 \%$ and $10.2 \%$ for control and GE, respectively. Similar trend was observed in 18:2n6 and 18:3n3 which were significantly increased from $12.4 \%$ for initial to $13.4 \%$ and $14.0 \%$ and from $0.1 \%$ for initial to $1.3 \%$ and $1.5 \%$ for control and GE, respectively. As a whole, lower saturated fatty acids (SFA) and monounsaturated fatty acids (MUFA) and higher polyunsaturated fatty acids (PUFA) were found in GE than in initial and control, suggesting that dietary GE could stimulate the accumulation of $20: 5 n 3$ and $22: 6 n 3$ in 
Table 4. Fatty acid profile ( $\%$ of total fatty acids) in the experimental diet and whole body of initial and final fish fed diets for 5 wks ${ }^{1}$

\begin{tabular}{|c|c|c|c|c|}
\hline \multirow{2}{*}{ Fatty acid } & \multirow{2}{*}{ Diet } & \multirow{2}{*}{ Initial } & \multicolumn{2}{|c|}{ Experimental groups } \\
\hline & & & Control & GE \\
\hline $\bar{C} 14: 0$ & $5.29 \pm 0.08$ & $4.70 \pm 0.60^{\mathrm{a}}$ & $4.15 \pm 0.68^{\mathrm{ab}}$ & $3.86 \pm 0.07^{\mathrm{b}}$ \\
\hline C14:1 & $0.15 \pm 0.01$ & $0.17 \pm 0.01^{\mathrm{a}}$ & $0.14 \pm 0.02^{\mathrm{b}}$ & $0.14 \pm 0.00^{\mathrm{b}}$ \\
\hline C15:0 & $0.65 \pm 0.03$ & $0.65 \pm 0.05^{\mathrm{a}}$ & $0.53 \pm 0.08^{b}$ & $0.50 \pm 0.01^{\mathrm{b}}$ \\
\hline C15:1 & $0.08 \pm 0.01$ & $0.10 \pm 0.06^{\mathrm{a}}$ & $0.07 \pm 0.01^{\mathrm{b}}$ & $0.07 \pm 0.00^{\mathrm{b}}$ \\
\hline C16:0 & $20.78 \pm 0.21$ & $24.89 \pm 0.03^{\mathrm{a}}$ & $22.48 \pm 1.29^{\mathrm{b}}$ & $21.32 \pm 0.20^{\mathrm{b}}$ \\
\hline C16:1 & $6.75 \pm 0.03$ & $6.80 \pm 0.18^{\mathrm{ns}}$ & $6.70 \pm 0.50$ & $6.43 \pm 0.02$ \\
\hline C17:0 & $0.94 \pm 0.00$ & $0.39 \pm 0.03^{\mathrm{a}}$ & $0.32 \pm 0.04^{\mathrm{ab}}$ & $0.29 \pm 0.01^{\mathrm{b}}$ \\
\hline $\mathrm{C} 17: 1$ & $0.80 \pm 0.00$ & $0.47 \pm 0.01^{\mathrm{ns}}$ & $0.35 \pm 0.25$ & $0.40 \pm 0.05$ \\
\hline C18:0 & $4.70 \pm 0.01$ & $3.48 \pm 0.04^{\mathrm{a}}$ & $3.06 \pm 0.27^{\mathrm{b}}$ & $2.59 \pm 0.14^{\mathrm{c}}$ \\
\hline C18:1n9 & $16.54 \pm 0.03$ & $30.05 \pm 1.33^{\mathrm{a}}$ & $29.26 \pm 0.81^{\mathrm{a}}$ & $26.80 \pm 0.47^{b}$ \\
\hline $\mathrm{C} 18: 2 \mathrm{n} 6$ & $15.41 \pm 0.10$ & $12.41 \pm 0.11^{\mathrm{c}}$ & $13.41 \pm 0.03^{\mathrm{b}}$ & $13.99 \pm 0.09^{\mathrm{a}}$ \\
\hline C18:3n6 & $0.19 \pm 0.00$ & $0.32 \pm 0.07^{\mathrm{ab}}$ & $0.26 \pm 0.05^{\mathrm{b}}$ & $0.41 \pm 0.07^{\mathrm{a}}$ \\
\hline $\mathrm{C} 18: 3 \mathrm{n} 3$ & $1.74 \pm 0.00$ & $0.99 \pm 0.22^{\mathrm{c}}$ & $1.33 \pm 0.19^{\mathrm{b}}$ & $1.53 \pm 0.02^{\mathrm{a}}$ \\
\hline C20:1 & $1.48 \pm 0.01$ & $3.26 \pm 0.08^{\mathrm{ns}}$ & $2.98 \pm 0.32$ & $2.68 \pm 0.00$ \\
\hline C20:2n6 & $0.17 \pm 0.02$ & $0.90 \pm 0.01^{\mathrm{b}}$ & $0.98 \pm 0.03^{\mathrm{a}}$ & $0.98 \pm 0.00^{\mathrm{a}}$ \\
\hline C21:0 & $1.09 \pm 0.01$ & $0.78 \pm 0.05^{\mathrm{b}}$ & $0.96 \pm 0.17^{\mathrm{b}}$ & $1.14 \pm 0.03^{\mathrm{a}}$ \\
\hline$C 20: 5 n-3$ & $7.62 \pm 0.08$ & $2.14 \pm 0.07^{\mathrm{c}}$ & $3.28 \pm 1.09^{\mathrm{b}}$ & $4.23 \pm 0.14^{\mathrm{a}}$ \\
\hline C22:1 & $0.27 \pm 0.02$ & $1.29 \pm 0.15^{\mathrm{a}}$ & $0.89 \pm 0.46^{\mathrm{ab}}$ & $0.52 \pm 0.20^{\mathrm{b}}$ \\
\hline $\mathrm{C} 24: 0$ & $1.71 \pm 0.04$ & $1.00 \pm 0.10^{\mathrm{c}}$ & $1.52 \pm 0.48^{\mathrm{b}}$ & $1.96 \pm 0.02^{\mathrm{a}}$ \\
\hline$C 22: 6 n-3$ & $12.00 \pm 0.18$ & $5.21 \pm 0.25^{\mathrm{b}}$ & $7.31 \pm 2.91^{\mathrm{b}}$ & $10.16 \pm 0.31^{\mathrm{a}}$ \\
\hline $\mathrm{SFA}^{2}$ & $36.65 \pm 0.70$ & $35.89 \pm 0.84^{\mathrm{a}}$ & $33.02 \pm 1.72^{\mathrm{b}}$ & $31.67 \pm 0.31^{\mathrm{c}}$ \\
\hline MUFA $^{3}$ & $25.91 \pm 0.29$ & $42.14 \pm 1.38^{\mathrm{a}}$ & $40.39 \pm 2.35^{\mathrm{a}}$ & $37.04 \pm 0.31^{\mathrm{b}}$ \\
\hline PUFA $^{4}$ & $37.44 \pm 0.57$ & $21.97 \pm 0.53^{b}$ & $26.59 \pm 4.07^{\mathrm{b}}$ & $31.29 \pm 0.62^{\mathrm{a}}$ \\
\hline
\end{tabular}

${ }^{1}$ Values are means \pm SE of five replicates with 2 determinations per replicate for initial and each final group. Means with different superscripts in the same row are significantly different $(\mathrm{p}<0.05)$. $\mathrm{ns}=$ Non significant $(\mathrm{p}>0.05)$.

${ }^{2}$ Saturated fatty acids. ${ }^{3}$ Monounsaturated fatty acids. ${ }^{4}$ Polyunsaturated fatty acids.

fish body.

\section{Hematocrit and hemoglobin analysis}

Hematological characteristics of juvenile sterlet sturgeon fed diets with or without GE for 5 wks are given in Table 5. Mean values for PCV (hematocrit) and $\mathrm{Hb}$ (hemoglobin) were significantly different $(\mathrm{p}<0.05)$ between control (PCV, 22.0\%; Hb $10.2 \mathrm{~g} / \mathrm{dl}$ ) and GE groups (PCV, $25.4 \%$; Hb $11.4 \mathrm{~g} / \mathrm{dl})$.

\section{Postprandial glycaemic response and blood plasma change}

Plasma glucose and insulin concentrations of sterlet

Table 5. Hematological characteristics of juvenile sterlet sturgeon fed diets for $5 \mathrm{wks}$

\begin{tabular}{lcc}
\hline \multirow{2}{*}{ Parameters } & \multicolumn{2}{c}{ Experimental groups } \\
\cline { 2 - 3 } & Control & GE \\
\hline $\mathrm{PCV}(\%)^{2}$ & $22.0 \pm 1.87$ & $25.4 \pm 1.67^{*}$ \\
$\mathrm{Hb}(\mathrm{g} / \mathrm{dl})^{3}$ & $10.2 \pm 0.57$ & $11.4 \pm 0.56^{*}$ \\
\hline
\end{tabular}

\footnotetext{
${ }^{1}$ Values are means \pm SD of five fish for each group. Means with the asterisk $*$ in the same row indicates significant difference $(\mathrm{p}<0.05)$ between two groups

${ }^{2}$ Hematocrit. ${ }^{3}$ Hemoglobin.
}

sturgeon fed diets with or without GE are shown in Table 6. Glucose level (mg/dl) of control fish 1 and $12 \mathrm{~h}$ after meal increased from 62.4 to 74.6 and it remained constant at 73.6 $24 \mathrm{~h}$ after meal. However, the value $24 \mathrm{~h}$ after meal of GE group sharply decreased to 57.6, while similar change from 50.8 to 73.0 was observed 1 and $12 \mathrm{~h}$ after meal. Significant difference $(\mathrm{p}<0.05)$ in glucose level 1 and $24 \mathrm{~h}$ after meal was observed between two groups and the value in $12 \mathrm{~h}$ was significantly higher $(\mathrm{p}<0.05)$ than those in 1 and $24 \mathrm{~h}$ in GE

Table 6. Postprandial glycaemic response of juvenile sterlet sturgeon $^{1}$

\begin{tabular}{cccc}
\hline \multirow{2}{*}{ Parameters } & $\begin{array}{c}\text { Time }(\mathrm{h}) \\
\text { after meal }\end{array}$ & \multicolumn{2}{c}{ Experimental groups } \\
\cline { 3 - 4 } & 1 & $62.4 \pm 5.59^{\mathrm{b}}$ & $50.8 \pm 9.31^{\mathrm{b} *}$ \\
\hline Glucose & 12 & $74.6 \pm 9.86^{\mathrm{a}}$ & $73.0 \pm 12.14^{\mathrm{a}}$ \\
$(\mathrm{mg} / \mathrm{dl})$ & 24 & $73.6 \pm 12.58^{\mathrm{a}}$ & $57.6 \pm 11.41^{\mathrm{b} *}$ \\
& 1 & $5.06 \pm 0.56^{\mathrm{a}}$ & $10.56 \pm 5.80^{\mathrm{a} *}$ \\
Insulin & 12 & $2.72 \pm 0.77^{\mathrm{b}}$ & $2.60 \pm 1.47^{\mathrm{b}}$ \\
$(\mu \mathrm{IU} / \mathrm{ml})$ & 24 & $2.96 \pm 1.13^{\mathrm{b}}$ & $32.56 \pm 28.53^{\mathrm{a} *}$ \\
& &
\end{tabular}

${ }^{1}$ Values are means \pm SD of five fish for each group. Means with same superscripts in the same column are not significantly different ( $p>0.05)$ among $\mathrm{h}$ after each meal. Means with the asterisk* in same row indicates significant difference $(\mathrm{p}<0.05)$ between two groups. 
group. On the other hand, insulin level $(\mu \mathrm{IU} / \mathrm{ml})$ of control in 1 and $12 \mathrm{~h}$ decreased from 5.06 to 2.72 and remained constant at 2.96 in $24 \mathrm{~h}$. In contrast, the value of GE decreased from 10.56 to 2.60 and highly increased to 32.56 in each interval of time. Significant difference $(p<0.05)$ in the value $24 \mathrm{~h}$ after meal was observed between two groups. However, there was no significant difference $(p>0.05)$ between the values in $1 \mathrm{~h}$ and $12 \mathrm{~h}$ in GE group. The serological characteristics of juvenile sterlet sturgeon fed the experimental diets are shown in Table 7. Glutamic oxaloacetic transaminase (GOT) ranged from 304 to 312 $\mathrm{U} / \mathrm{L}$ for control and from 270 to $327 \mathrm{U} / \mathrm{L}$ for GE. Glutamic pyruvic transaminase (GPT) ranged from 11 to $74 \mathrm{U} / \mathrm{L}$ for control and from 17 to $64 \mathrm{U} / \mathrm{L}$ for GE. Albumin (ALB) level after meal was relatively constant at 0.32 to $0.38 \mathrm{~g} / \mathrm{dl}$ and at 0.34 to $0.40 \mathrm{~g} / \mathrm{dl}$ for control and GE, respectively. Total protein (TP) level increased from 1.26 to $1.70 \mathrm{~g} / \mathrm{dl}$ for control and from 1.54 to $1.94 \mathrm{~g} / \mathrm{dl}$ for GE. Total cholesterol (TCHO) level $1 \mathrm{~h}$ after meal was significantly higher $(\mathrm{p}<0.05)$ in GE $(48.4 \mathrm{mg} / \mathrm{dl})$ than in control $(28.8 \mathrm{mg} / \mathrm{dl})$, since that time, the values were not greatly different both in 12 (36.4 vs $37.4 \mathrm{mg} / \mathrm{dl})$ and $24 \mathrm{~h}(41.6 \mathrm{vs} 50.0 \mathrm{mg} / \mathrm{dl})$. Triglyceride (TG) level after meal increased from 578 to $678 \mathrm{mg} / \mathrm{dl}$ for control and from 638 to $816 \mathrm{mg} / \mathrm{dl}$ for GE. It was found that the value in $24 \mathrm{~h}$ was significantly different $(\mathrm{p}<0.05)$ between two groups.

\section{Liver composition}

Liver proximate composition of initial and final sturgeon fed diets with or without GE for 23 days is shown in Table 8. Liver weight increased from $1.87 \mathrm{~g}$ for initial to $2.76 \mathrm{~g}$ for control. The highest HSI $(2.85 \%)$ was found in control, while it was not significantly different $(\mathrm{p}>0.05)$ between initial $(2.43 \%)$ and GE $(2.37 \%)$ group. Liver moisture significantly decreased $(p<0.05)$ in two experimental groups, compared to that $(63.6 \%)$ of initial. Similar trend was shown in protein level, which was decreased from $10.9 \%$ for initial to $7.9 \%$ for control. In
Table 7. Blood plasma changes of juvenile sterlet sturgeon ${ }^{1}$

\begin{tabular}{cccc}
\hline \multirow{2}{*}{ Parameters } & $\begin{array}{c}\text { Time }(\mathrm{h}) \\
\text { after meal }\end{array}$ & \multicolumn{2}{c}{ Experimental groups } \\
\cline { 3 - 4 } & 1 & $304.6 \pm 17.66$ & $280.4 \pm 62.54$ \\
$\mathrm{GOT}^{2}$ & 12 & $312.4 \pm 50.13$ & $270.4 \pm 104.45$ \\
& 24 & $303.6 \pm 28.08$ & $326.8 \pm 73.08$ \\
$\mathrm{GPT}^{3}$ & 1 & $11.0 \pm 3.54$ & $16.6 \pm 5.59$ \\
$(\mathrm{U} / \mathrm{L})$ & 12 & $23.8 \pm 10.03$ & $19.2 \pm 7.98$ \\
& 24 & $73.6 \pm 2.70$ & $64.4 \pm 12.90$ \\
$\mathrm{ALB}^{4}$ & 1 & $0.32 \pm 0.04$ & $0.34 \pm 0.05$ \\
$(\mathrm{~g} / \mathrm{dl})$ & 12 & $0.38 \pm 0.08$ & $0.36 \pm 0.03$ \\
& 24 & $0.38 \pm 0.04$ & $0.40 \pm 0.01$ \\
$\mathrm{TP}^{5}$ & 1 & $1.26 \pm 0.89$ & $1.54 \pm 0.27$ \\
$(\mathrm{~g} / \mathrm{dl})$ & 12 & $1.58 \pm 1.55$ & $1.54 \pm 0.38$ \\
& 24 & $1.70 \pm 0.17$ & $1.94 \pm 0.46$ \\
$\mathrm{TCHO}^{6}$ & 1 & $28.8 \pm 3.49$ & $48.4 \pm 5.07 * *$ \\
$(\mathrm{mg} / \mathrm{dl})$ & 12 & $36.4 \pm 8.20$ & $37.4 \pm 12.86$ \\
& 24 & $41.6 \pm 4.28$ & $50.0 \pm 7.79$ \\
$\mathrm{TG}^{7}$ & 1 & $578.4 \pm 90.80$ & $638.0 \pm 150.61$ \\
$(\mathrm{mg} / \mathrm{dl})$ & 12 & $722.4 \pm 113.08$ & $719.2 \pm 64.89$ \\
& 24 & $678.0 \pm 52.06$ & $816.0 \pm 75.67 *$ \\
\hline
\end{tabular}

${ }^{1}$ Each value represents a means \pm SD of 5 fish for each group per hour after meal. Means with the asterisk* in the same row are significantly different $(* \mathrm{p}<0.05$, ** $\mathrm{p}<0.01)$ between two groups.

${ }^{2}$ Glutamic oxaloacetic transaminase. ${ }^{3}$ Glutamic pyruvic transaminase.

${ }^{4}$ Albumin. ${ }^{5}$ Total protein. ${ }^{6}$ Total carbohydrate. ${ }^{7}$ Triglyceride.

contrast, lipid significantly increased from $22.5 \%$ for initial to $30.0 \%$ for GE. Fish fed control had $27.2 \%$ lipid in their liver, which was significantly lower $(\mathrm{p}<0.05)$ than that of $0.5 \%$ GE. Ash level did not show any significant difference ( $>0.05$ ) among initial, control and GE, ranging from $0.89 \%$ to $0.99 \%$.

\section{DISCUSSION}

Garlic contains a variety of organosulfur compounds such as allicin, ajoene, S-allylcysteine, diallyl disulfide,

Table 8. Proximate composition (\%, as-is basis) of liver of initial and final sturgeon fed diets for $23 \mathrm{~d}^{1}$

\begin{tabular}{lccc}
\hline \multirow{2}{*}{ Items } & \multicolumn{3}{c}{ Experimental groups } \\
\cline { 2 - 4 } & Initial & Control & $0.5 \%$ GE \\
\hline Sampled fish no. & 8 & 10 & 10 \\
Fish weight $(\mathrm{g}, \mathrm{M} \pm \mathrm{SD})$ & $64.67 \pm 15.13$ & $97.0 \pm 12.06$ & $101.4 \pm 22.17$ \\
Liver weight $(\mathrm{g}, \mathrm{M} \pm \mathrm{SD})$ & $1.87 \pm 0.43$ & $2.76 \pm 0.59$ & $2.44 \pm 0.80$ \\
$\mathrm{HSI}^{2}$ & $2.43 \pm 0.27^{\mathrm{b}}$ & $2.85 \pm 0.50^{\mathrm{a}}$ & $2.37 \pm 0.38^{\mathrm{b}}$ \\
Proximate composition $(\%)^{3}$ & & & \\
$\quad$ Moisture & $63.6 \pm 0.34^{\mathrm{a}}$ & $59.6 \pm 0.01^{\mathrm{b}}$ & $57.1 \pm 0.53^{\mathrm{b}}$ \\
Crude protein & $10.9 \pm 0.30^{\mathrm{a}}$ & $7.90 \pm 0.02^{\mathrm{c}}$ & $8.83 \pm 0.08^{\mathrm{b}}$ \\
Crude lipid & $22.5 \pm 0.42^{\mathrm{c}}$ & $27.2 \pm 0.48^{\mathrm{b}}$ & $30.0 \pm 0.42^{\mathrm{a}}$ \\
Crude ash & $0.99 \pm 0.07^{\mathrm{a}}$ & $0.89 \pm 0.01^{\mathrm{a}}$ & $0.98 \pm 0.07^{\mathrm{a}}$ \\
\hline
\end{tabular}

\footnotetext{
${ }^{1}$ Values (means \pm SE) with different superscripts in the same row indicate significant difference $(\mathrm{p}<0.05)$.

${ }^{2}$ Hepatosomatic index; (liver weigh $(\mathrm{g}) \times 100 /$ body weight $(\mathrm{g})$ ). ${ }^{3}$ Values are means \pm SE of 3 replicates with 2 determinations of each replicate sample.
} 
S-methylcysteine sulfoxide and S-allylcysteine (Chi et al., 1982). A wide array of beneficial effects of garlic such as antihypertensive, antihyperlipidemic, antimicrobial, hypoglycaemic, antidote (for heavy metal poisoning), anticarcinogenic, hepatoprotective and immunomodulation have been reported by several researchers (Foushee et al., 1982; Macmahon and Vargus, 1993; Agarwal, 1996; Augusti, 1996; Bordia et al., 1996; Yeh and Liu, 2001). Allyl sulfides in garlic enhance glutathione S-transferase enzyme system and garlic also has immune enhancing activities that include promotion of lymphocyte synthesis, cytokine release, phagocytosis and natural killer cell activity (Kyo et al., 1998). Studies on garlic as an alternative of growth promoter in livestock production were conducted and its beneficial effects on growth, digestibility and carcass traits have been reported (Bampids et al., 2005; Tatara et al., 2008). There is a lot of anecdotal evidences about the use and effectiveness of garlic for fish. Much of these are positive, but there are also negative anecdotal reviews of the use of garlic. In livestock, a few research suggested that garlic did not affect growth performance (Horton et al., 1991; Freitas et al., 2001; Bampidis et al., 2005) because the pungent smell may lead to lower diet palatability.

Insulin is derived from a larger single chain precursor protein, proinsulin (Steiner and Oyer, 1967) which contains 81 amino acids and three disulfide bonds. Insulin itself consists of an A-chain usually of 21 amino acids and a B-chain usually of 30 amino acid residues connected by two disulfide bonds. In Russian sturgeon, the amino acid sequence of sturgeon insulin (A-chain; 21-amino-acid peptide, H-Gly-Ile-Val-Glu-Gln-Cys-Cys-His-Ser-Pro-CysSer-Leu-Tyr-Asp-Leu-Glu-Asn-Tyr-Cys-Asn-OH and Bchain; 31-amino-acid peptide, H-Ala-Ala-Asn-Gln-HisLeu-Cys-Gly-Ser-His-Leu-Val-Glu-Ala-Leu-Tyr-Leu-ValCys-Gly-Glu-Arg-Gly-Phe-Phe-Tyr-Thr-Pro-Asn-Lys-Val$\mathrm{OH})$ is more similar to the amino acid sequence of mammalian insulins than of other fish insulins (Rusakov et al., 1998). The homeostatic role of insulin in mammals was succinctly summarized by Tashima and Cahill (1968). After feeding, insulin facilitates glucose uptake and incorporation into glycogen or conversion into lipid and stimulates amino acid incorporation into protein. In addition, insulin promotes incorporation of dietary lipid into adipose tissue and regulates plasma concentrations of glucose, amino acids and free fatty acids during fasting. The present study showed that the hypoglycaemic effect for juvenile sterlet sturgeon fed diet with $0.5 \%$ GE was accompanied with blood plasma glucose depletion and elevated blood plasma insulin (after $1 \mathrm{~h}$ and $24 \mathrm{~h}$ of meal). These results are similar to those reported in rats (Chang and Johnson, 1980; Augusti and Sheela, 1996; Preuss et al., 2001), where there is an association between garlic administration and the rise in circulating insulin. Jain et al. (1973) reported that garlic juice improved hyperglycaemia as compared with an insulin-secretagogue drug (tolbutamide) on studying glucose tolerance in rabbits. In various mammal species, the hypoglycemic and antidiabetic effect of garlic has been found (Chang and Johnson, 1980; Sheela and Augusti, 1992; Augusti, 1996; Kasuga et al., 1999) and can suppress the rise in hyperglycaemia and hyperlipidaemia in diabetic animals. The administration of the insulin secretagogue drug chlorpropamide in fish leads to the hypoglycaemic effects (Al-Salahy, 2003) and insulin injections into fish also induced hypoglycaemia (Ottolenghi et al., 1982; Carneiro and Amaral, 1983; Al-Salahy et al., 1994). These findings are similar to those resulting from garlic treatment (Al-Salahy and Mahmoud, 2003). Thus, our research suggested that garlic in diet for juvenile sterlet sturgeon (60 to $100 \mathrm{~g}$ ) has positive effect on hypoglycaemia.

Fish and all animals need a constant source of amino acids for tissue protein synthesis and for synthesis of other compounds associated with metabolism, including hormones, neurotransmitters, purines and metabolic enzymes (Harlver and Hardy, 2002). Fish body proteins cannot be stored in major quantities and are continuously renewed through degradation and synthesis, free amino acid pool changes in its composition (profile) and concentrations, depending on the tissue (Carter et al., 1993), frequency and time after feeding (Tantikitti and March, 1995) and temperature and food (Knapp and Wieser, 1981). Since there is a slower rate of protein turnover in muscle than in other organs (Fauconneau and Arnal, 1985), the influence of dietary treatments, especially dietary amino acid profiles, may be more responsive in other tissues than in muscle. It is well known that insulin exerts a profound influence on the metabolism of amino acids and protein (Lotspeich and Shelton, 1949). The evidence for the role of insulin in the regulation of protein synthesis in fish was provided by Jackim and LaRoche (1973) who showed that injection of bovine insulin $1 \mu \mathrm{g} / \mathrm{fish}$ into Fundulus heteroclitus weighing 1 to $1.5 \mathrm{~g}$ resulted in stimulation of $\left[{ }^{14} \mathrm{C}\right]$ leucine incorporation from $45.6 \%$ in controls to $73.4 \% 18 \mathrm{~h}$ after injection. In a study on the European silver eel, Anguilla anguilla, Ince and Thorpe (1974) reported that $2 \mathrm{IU} / \mathrm{kg}$ cod insulin lowered blood glucose, amino acid nitrogen and cholesterol while bovine insulin at the same dosage lowered amino acid nitrogen only. Insulin was also implicated in the rapid clearance of an intraarterial load of amino acids. A study on the Japanese eel, Anguilla japonica, has shown that insulin at $5 \mathrm{IU} / \mathrm{kg}$ reduces the plasma concentration of all amino acids except citrulline (Inui et al., 1975). In the present study, whole body amino acid composition between both groups of fish was not different (Table 1). However, the levels of total whole body free amino acids decreased in GE group (Table 2), while total free amino acid level in 
muscle of GE group was higher than that of control group (Table 3). Our previous research suggested dietary garlic for juvenile sterlet sturgeon (60 to $100 \mathrm{~g}$ ) could positively affect growth performance and $\mathrm{N}$ retention (Lee et al., 2012). The body amino acid pool is in a continuous state of flux in order to keep the pool relatively constant and amino acids are discretely released for synthetic purposes, oxidation for energy release, or conversion to fat. The promotion in insulin of GE group may induce acceleration for blood FAA uptake into muscle to strength growth performance.

Dietary lipids are important nutrients affecting energy production in most of fish and essential for growth and development. But, fish are known to utilize protein preferentially to lipid or carbohydrate as an energy source. Lipids are stored in several tissues and at high levels in sturgeon. Sturgeon may have muscle lipid content as high as or higher than that of other fish that are considered fatty, such as salmon and mackerel (Krzynowek and Murphy, 1987). Sturgeon fed high lipid diets preferentially deposits lipid in the liver and the digestive tract rather than in muscle (Decker et al., 1991). In present study, lipid in liver composition (Table 8) of juvenile sterlet sturgeon was greatly increased from $22.5 \%$ for initial to $27.2 \%$ and $30.0 \%$ for control and GE groups, respectively. Dietary GE might result in excessive lipid aggregation in liver because increase in protein utilization by fish fed GE diet could reduce role of lipid as an energy source for growth.

In this study, we were particularly interested in the levels of (n-3) PUFA [DHA, 20:5(n-3) and EPA, 22:6(n-3)] in whole body. It has been shown that (n-3) PUFA have several beneficial effects on human health (Simopoulos, 1989) and, in general, wild fish are considered to be the richest source of dietary (n-3) PUFA. It was reported that farm-raised fish have a lower level of (n-3) PUFA than their wild counterparts (Pigott, 1989). Greene and Selivonchick (1987) suggested that different species of fish have varying abilities to desaturate and elongate fatty acids. Rainbow trout have a relatively high ability to desaturate and elongate fatty acids, whereas some marine fish have a poor ability to do so. Xu et al. (1993) reported that white sturgeon has the ability to desaturate and elongate 18:2(n-6) and 18:3(n-3), so they could utilize the different lipids equally well. In the past, research has been focused to reduce fat, cholesterol, and SFA contents of poultry meat by dietary supplementation of garlic (Konjufca et al., 1997). Ao et al. (2010) reported that in fatty acids composition of egg yolk in laying hens, $3.0 \%$ fermented garlic powder supplementation resulted in a higher PUFA:SFA ratio compared with other treatments (control, 1\%, 2\% fermented garlic powder supplementation). Our present finding also accords with these results that juvenile sterlet sturgeon fed diet with GE have lower SFA and MUFA with higher PUFA than initial and control fish, suggesting that dietary GE could increase the accumulation of $20: 5 \mathrm{n} 3$ and $22: 6 \mathrm{n} 3$ in fish body. However, no comparisons with other studies could be made because investigations on the use of GE in relation to any sturgeon meat quality have not yet been reported.

In Table 5, it is shown that the hematocrit and hemoglobin level were higher in fish fed GE than in fish fed control diet. Shau et al. (2007) reported that the haemoglobin content was significantly $(\mathrm{p}<0.05)$ higher in the GE group (10 g garlic $\mathrm{kg}^{-1}$ feed) after $20 \mathrm{~d}$. Leucocytes and erythrocytes play a non-specific or innate immunity and their count can be considered as an indicator of the health status of fish (Harikrishnan et al., 2003). The erythrocyte count increased with the administration of garlic, which might indicate an immunostimulant effect (Sahu, 2004). Attention has been focused on the changes in GOT and GPT activities which promote gluconeogenesis from amino acid, as well as on the changes in aminotransferase activities in the liver (Rashatuar and Ilyas, 1983; Abd-ElHamid et al., 2002). In recent years, although some studies reported that the enzyme activities in serum of animals decreased significantly when they were fed diet containing garlic (Salah El-Deen and Rogers, 1993; Augusti and Sheela, 1996; EL-Shatter et al., 1997), our result did not show any significant difference in both GOT and GPT activities in blood plasma of both GE and control groups. Al-Salahy (2002) did not found a positive effect of garlic administration ( $5 \mathrm{~h}$ and $5 \mathrm{~d}$ ) on serum TP and ALB to fish, Clarias lazera. Similarly, the present results did not showed any significant difference on TP and ALB level between GE and control groups. However, Metwally (2009) showed that total protein in serum was significantly high with fish fed diet containing any source of garlic (natural garlic, garlic powder, garlic oil). Although Yeh and Yeh (1994) revealed that sulfur compounds of garlic decreased the plasma concentration of cholesterol in rat resulting possibly from an inhibition of hepatic cholesterol synthesis. In our study dietary GE did not affect cholesterol level in the different hours except $1 \mathrm{~h}$ after meal. Reduction of triglycerides in blood serum of $O$. niloticus fed diets containing different forms of garlic was reported by Metwally (2009). However, Al-Salahy (2002) reported that the triglyceride level did not change, as well, level of serum total lipid remained same in the garlic administrated ( $5 \mathrm{~d}$ ) group. Our results obtained no significant difference between GE and control groups in TG except $24 \mathrm{~h}$ after meal. Considering the data obtained herein and the above discussion, it was concluded that the supplementation of GE could influence amino acids levels of whole body and muscle, $\mathrm{N}$ utilization, whole body fatty acid composition and blood plasma content in juvenile 
sterlet sturgeon. However, further research is needed to validate the present results.

\section{ACKNOWLEDGEMENTS}

We would like to thank Gyeonggi Province Freshwater Fisheries Research Institute for donating the fish and providing the facility.

\section{REFERENCES}

Abd-El-Hamid, A. M., F. F. Khalil, M. I. EL-Barbery, V. H. Zaki and H. S. Husien. 2002. Feeding Nile tilapia on biogen to detoxify aflatoxin diet. In: Annual Scientific Conference of Animal and Fish Production 1. Proceedings Mansoura University. pp. 207-230.

Agarwal, K. C. 1996. Therapeutic actions of garlic constituents Med. Res. Rev. 16:111-124.

Ahmed, R. S. and S. B. Sharma. 1997. Biochemical studies on combined effects of garlic Allium sativum (Linn) and ginger Zingiber officinale (Rose) in albino rats. Indian J. Exp. Biol. 35:841-843.

Al-Salahy, M. B., A. A. Hassanien., S. H. M. Ahmed and S. Y. Hussein. 1994. Metabolic effect of insulin on carbohydrate and free amino acid contents in the Nile fish, Oreochromis niloticus. Bull. Fac. Assiut.Univ. 23(2-E):51-66.

Al-Salahy, M. B. 2002. Some physiological studies on the effect of onion and garlic juices on the fish, Clarias lazera. Fish. Physiol. Biochem. 27:129-142.

Al-Salahy, M. B. 2003. Some metabolic effects of glucose and chlorpropamide administration on the liver and white muscle in Clarias lazera. J. Egypt. Ger. Soc. Zool. 42A:57-75.

Al-Salahy, M. B. and A. A. B. Mahmoud. 2003. Metabolic and histological studies on the effect of garlic administration on the carnivorous fish Chrysichthys auratus. Egypt. J. Biol. 5:94107.

AOAC. 1995. Official methods of analysis. 16th ed. Association of Official Analytical Chemists. Arlington, Virginia, USA

Ao, X., J. S. Yoo, J. H. Lee, H. D. Jang, J. P. Wang, T. X. Zhou and I. H. Kim. 2010. Effects of fermented garlic powder on production performance, egg quality, blood profiles and fatty acids composition of egg yolk in laying hens. Asian-Aust. J. Anim. Sci. 23:786-791.

Augusti, K. T. 1996. Therapeutic values of onion (Allium cepa L) and garlic (Allium sativum L). Indian. J. Exp. Biol. 34:634-640.

Augusti, K. T. and C. G. Sheela. 1996. Antiperoxide effect of sallyl cysteine sulfoxide, an insulin secretagogue, in diabetic rats. Experientia 52:115-119.

Bampidis, V. A., V. Christodoulou, E. Christaki, P. Florou-Paneri and A. B. Spais. 2005. Effect of dietary garlic bulb and garlic husk supplementation on performance and carcass characteristics of growing lambs. Anim. Feed Sci. Technol. 121:273-283.

Bordia, A., S. K. Verma and K. C. Srivastava. 1996. Effect of garlic on platelet aggregation in humans: A study in healthy subjects and patients with coronary artery disease. Prostoglandins Leukot.Essent. Fatty Acids 55:201-205.

Brown, B. A. 1980. Routine hematology procedures. In
Hematology: Principles and Procedures. pp. 71-112.

Carneiro, N. M. and A. D. Amaral. 1983. Effect of insulin and glucagon on plasma glucose levels and glycogen contents in organs of the freshwater teleost, Pimelodus maculates. Gen. Comp. Endocrinol. 49:115-121.

Carter, C. G., D. F. Houlihan, B. Buchanan and A. I. Mitchell. 1993. Protein-nitrogen flux and protein growth efficiency of individual Atlantic Salmon (Salmo salar L.). Fish Physiol. Biochem. 12:305-315.

Chang, M. W. and M. Johnson. 1980. Effect of garlic on carbohydrate metabolism and lipid synthesis in rats. J. Nutr. 110:931-936

Chi, M. S., E. T. Koh and T. J. Steward. 1982. Effects of garlic on lipid metabolism in rats fed cholesterol or lard. J. Nutr. 112:241-248

Citarasu, T., M. M. Babu, S. M. J. Punitha, K. Venket Ramalingam and M. P. Marian. 2001. Control of pathogenic bacteria using herbal biomedicinal products in the larviculture system of Penaeus monodon. International Conference on Advanced Technologies in Fisheries and Marine Sciences, MS University, India. pp. 104.

Citarasu, T., R. R. Sekar, M. M. Babu and M. P. Marian. 2002. Developing Artemia enriched herbal diet for producing quality larvae in Penaeus monodon. Asian. Fish. Sci. 15:21-32.

Decker, E. A., A. D. Crum, S. D. Mims and J. H. Tidwell. 1991. Processing yield and composition of paddlefish (Polyodon spathula), a potential aquaculture species. J. Agric. Food Chem. 39:686-688.

Diab, A. S., G. O. EL-NAGAR and Y. M. Abd-El-Hady. 2002. Evaluation of Nigella sativa L (black seeds; baraka), Allium sativum (garlic) and BIOGEN as feed additives on growth performance and immunostimulants of $O$. niloticus fingerlings. Suez Canal Vet. Med. J. pp.745-775.

Duncan, D. B. 1955. Multiple range and multiple ' $F$ 'tests. Biometrics 11:1-42.

EL-Shatter, M. A., M. H. Sobbhy and J. G. Shehab. 1997. Some pharmacological and pathological studies on Allium sativum (garlic). Appl. Vet. Med. J. 36:264-283.

Fauconneau, B. and M. Arnal. 1985. In vivo protein synthesis in different tissues and the wholebody of rainbow trout (Salmo gairdneri R.). Influence of environmental temperature. Comp. Biochem. Physiol. 82:179-187.

Fernández-Navarro, M., J. Peragón, F. Esteban, M. Higuera and J. A. Lupiáñez. 2006. Maslinic acid as a feed additive to stimulate growth and hepatic protein-turnover rates in rainbow trout (Onchorhynchus mykiss). Comp. Biochem. Physiol. Part C. $144: 130-140$.

Foushee, D. B., J. Ruffin and U. Banerjee. 1982. Garlic as a natural agent for the treatment of hypertension: a preliminary report. Cytobios 34:145-152.

Greene, D. H. S. and D. P. Selivonchick. 1987. Lipid metabolism in fish. Prog. Lipid Res. 26:53-85.

Harikrishnan, R., M. Nisha Rani and C. Balasundaram. 2003. Hematological and biochemical parameters in common carp, Cyprinus carpio, following herbal treatment for Aeromonas hydrophila infection. Aquaculture 221:41-50.

Harlver, J. E. and R. W. Hardy. 2002. Fish nutrition. 3rd edition. Academic press. San Diego, California, pp. 763-765.

Hochleithner, M. and J. Gessner. 1999. The sturgeon and 
paddlefish (Acipenseriformes) of the world. Biology and Aquaculture. AquaTech publications. p. 165.

Ince, B. W. and A. Thorpe. 1974. Effects of insulin and of metabolite loading on blood metabolites in the European silver eel, Anguilla anguilla L. Gen. Comp. Endocrinol. 23:460-471.

Inui, Y., S. Arai and M. Yokote. 1975. Gluconeogenesis in the eel. VI. Effects of hepatectomy, alloxan and mammalian insulin on the behavior of plasma amino acids. Nippon Suisan Gakkaishi 41:1105-1111.

Jackim, E. and G. LaRoche. 1973. Protein synthesis in Fundulus heteroclitus muscle. Comp. Biochem. Physiol. 44:851-866.

Jain, R. C., C. R. Vyas and O. P. Mahatma. 1973. Hypoglycemic action of onion and garlic. Lancet 2:1491.

Jayaprakas, V. and J. Eupharsia. 1996. Growth performance of Labeo rohita (Ham.) Livol (IHF-1000), an herbal product. Proc. Indian Natl. Sci. Acad. 63:1-10.

Kasuga, A., M. Ushijima, N. Morihara, Y. Itakura and Y. Nakata. 1999. Effect of aged garlic (AGE) on hyperglycemia induced by immobilization stress in mice. Nippon Yakurigaku Zasshi 114:191-197.

Knapp, E. and W. Wieser. 1981. Effect of temperature and food on the free aminoacids in tissue of roach (Rutilus rutilus L.) and rudd (Scardinius erythrophtalmus L.). Comp. Biochem. Physiol. 68:187-198.

Konjufca, V. H., G. M. Pesti and R. I. Bakalli. 1997. Modulation of cholesterol levels in broilers meat by dietary garlic and copper. Poult. Sci. 76:1264-1271.

Krzynowek, J. and J. Murphy. 1987. Prozimate composition, energy, fatty acid, sodium and cholesterol content finfish, shellfish, and their product. National Oceanic Atmosphere Administration Technical Report. 55:1-48.

Kyo, E., N. Uda, A. Suzuki, M. Kakimoto, M. Ushijima, S. Kasuga and Y. Itakura. 1998. Immunomodulation and antitumor activities of aged garlic extract. Phtomedicine 5:259267.

Lee, D. H., S. R. Lim, J. G. Han, S. Y. Hong, J. S. Choi, S. W. Lee, K. H. Kim and J. D. Kim. 2008. Effect of dietary garlic extracts on growth, feed utilization and whole body fatty acid composition of juvenile sterlet sturgeon. International symposium on fish nutrition and feeding. FXIII ISFNF. p. 203.

Lee, D. H., C. S. Ra, Y. H. Song, K. I. Sung and J. D. Kim. 2012. Effect of dietary garlic extracts on growth, feed utilization and whole body composition of juvenile sterlet sturgeon (Acipenser ruthenus). Asian-Aust. J. Anim. Sci. 25:577-583.

Lotspeich, W. D. and J. B. Shelton. 1949. The Role of insulin in the metabolism of amino acids. J. Biol. Chem. 179:175-180.

Macmahon, F. G. and R. Vargus. 1993. Can garlic lower blood pressure. A pilot study. Pharmacotherapy 13:406-407.

Metcalfe, L. D., A. A. Schmitz and J. R. Pelka. 1996. Rapid preparation of fatty acid esters from lipids for gas chromatographic analysis. Anal. Chem. 38:514-515.

Metwally, M. A. A. 2009. Effects of garlic (Allium sativum) on some antioxidant activities in Tilapia Nilotica (Oreochromis niloticus). World J. Fish. Marine Sci. 1:56-64.

Mims, S. D., A. Lazur, W. L. Shelton, B. Gomelsky and F. Chapman. 2000. Species profile. Production of sturgeon. Southern regional Aquaculture Center. SRAC Fact Sheet, Publication. No. 7200.

Ottolenghi, C., A. C. Puviani, A. Baruffaldi and L. Bringhenti.
1982. "In vivo" Effect of insulin on carbohydrate of catfish, Ictalurus malas. Comp. Biochem. Physiol. 72:32-41.

Pigott, G. M. 1989. The need to improve omega-3 content of cultured fish. World Aquaculture Magazine 20:63-68.

Preuss, H. G., D. Clouatre, A. Mohamadi and S. T. Jarrell. 2001. Wild garlic has a greater effect that regular garlic on blood pressure and blood chemistries of rats. Int. Urol. Nephrol. 32:525-530.

Rashatuar, S. S. and R. Ilyas. 1983. Effect of chronic herbicide intoxication on in vivo activities of certain enzymes in the liver of freshwater fish. Nemachelius denisonii. Toxicol. Lett. 16:249-252.

Rusakov, Y., S. Moriyama, V. M. Bondareva, A. P. Kolychev, Y. Amemiya, A. Yasuda and H. Kawauchi. 1998. Isolation and characterization of insulin in Russian sturgeon (Acipenser guldenstaedti). J. Pept. Res. 51:395-400.

Sahu, S. 2004. Antibacterial activity of plant extracts on fish microbial pathogens. MSc. Diss. CIFA. Kausalyaganga. Bhubaneswar. p. 237.

Sahu, S., B. K. Das, B. K. Mishra, J. Pradhan and N. Sarangi. 2007. Effect of Allium sativum on the immunity and survival of Labeo rohita infected with Aeromonas hydrophila. J. Appl. Ichthyol. 23:80-86.

Salah El-Deen, M. and W. A. Rogers. 1993. Changes in total protein and transaminase activities of grass carp exposed to diquat. J. Aquat. Anim. Health 5:280-286.

Shalaby, A. M., Y. M. Khattab and A. M. Abdel rahman. 2006. Effects of garlic (Allium sativum) and chloramphenicol on growth performance, physiological parameters and survival of Nile Tilapia (Oreochromis niloticus). J. Venom. Anim. Toxins incl. Trop. Dis. 12:172-201.

Sheela, C. G. and K. T. Augusti. 1992. Antidiabetic effects of Sallyl cysteine sulphoxide isolated from garlic, Allium sativum. Indian. J. Exp. Biol. 30:523-526.

Simopoulos, A. P. 1989. Summary of the NATO advanced research workshop on dietary $\omega 3$ and $\omega 6$ fatty acids: Biological Effects and Nutritional Essentiality. J. Nutr. 119:521-528.

Sivaram, V., M. M. Babu, T. Citarasu, G. Immanuel, S. Murugadass and M. P. Marian. 2004. Growth and immune response of juvenile greasy groupers (Epinephelus tauvina) fed with herbal antibacterial active principle supplemented diets against Vibrio harveyi infections. Aquaculture 237:9-20.

SPSS. Inc., 1999. SPSS Base 10.0 for Windows User's Guide. SPSS Inc., Chicago IL, USA.

Steiner, D. F. and P. E. Oyer. 1967. The biosynthesis of in sulin and probable precursor of in sulin by a huma islet cell adenoma. Proc. Natl. Acad. Sci. USA. 57:473-480.

Stimmelmayr, R., K. L. Drew and R. G. White. 2002. Serum insulin, glucose and lactate concentrations during 18 -h fast in female reindeer. Comp. Biochem. Physiol. Part B. 133:201208

Tantikitti, C. and B. E. March. 1995. Dinamics of plama free amino acid in rainbow trout (Oncorhynchus mykiss) under variety of dietary conditions. Fish Physiol. Biochem. 14:179194.

Tashima, L. and G. F. Cahill. 1968. Effects of Insulin the toadfish. Opsanus tau. Gen Comp. Endocrinol. 11:262-271.

Tatara, M. R., E. Sliwa, K. Dudek, A. Gawron and T. Piersiak. 2008. Aged garlic extract and allicin improve performance and 
gastrointestinal tract development of piglets reared in artificial sow. Ann. Agric. Environ. Med. 15:63-69.

Xu, R., S. S. O. Hung and J. B. German. 1993. White sturgeon tissue fatty acid compositions. J. Nutr. 123:1685-1692.

Yeh, Y. Y. and S. M. Yeh. 1994. Garlic reduces plasma lipids by inhibiting hepatic cholesterol and triacylglycerol synthesis. Lipids 29:189-193.
Yeh, Y. Y. and L. Liu. 2001. Cholesterol-Lowering effect of garlic extracts and or ganosulfur compounds: Human and animal studies. J. Nutr. 131:989s-993s.

Zimmerman, D. W. and B. D. Zumbo. 1993. Relative power of the Wilcoxon test, the Friedman test, and repeated-measures ANOVA on ranks. J. Exp. Educ. 62:75-86. 